\title{
The Influence of E-Commerce in Changing Competition in Regulated Industries: An Analysis in the Italian Sports Betting Market
}

\author{
Paolo Calvosa ${ }^{1}$ \\ ${ }^{1}$ Department of Economics, Management, Institutions (DEMI), University of Naples Federico II, Naples, Italy. \\ Correspondence: Paolo Calvosa, Department of Economics, Management, Institutions (DEMI), University of \\ Naples Federico II, Campus Monte S. Angelo, Via Cinthia 26, 80126, Naples, Italy. E-mail: calvosa@unina.it
}

Received: October 14, 2018

doi:10.5539/ijbm.v13n12p306
Accepted: November 23, 2018

Online Published: November 30, 2018

URL: https://doi.org/10.5539/ijbm.v13n12p306

\begin{abstract}
The effect of the Internet and e-commerce on industry competition has been widely discussed in economic-managerial literature. Most of the studies focused on the analysis of the impact of Internet technologies on specific industry structural factors - in particular on sectoral price levels -, but no sufficient empirical evidence based on overall industry change is yet available. The aim of this work is to analyze the influence of e-commerce on the transformation of the industrial structure and competition in a regulated market, that of Italian sports betting. This market, because the effect of a process of legalization of on-line sports betting that started in 2006, has been interested by a continuous shift of purchases of sport bets, ranging from the traditional sales channels to digital ones. This has contributed in creating an on-line gambling sector among the most developed and consolidated in the world. From a methodological point of view, firstly the data from a series of secondary sources was processed in order to examine the main changes in the Italian sports betting market induced by the legalization of on-line gambling. Secondly, the data and information collected through specific empirical investigations was used to examine the impact of Internet betting on gambling operators' business models and on players' gambling behavior in the Italian market. The results of the analysis has shown that the development of Internet technologies and of e-commerce has had, on the one hand, a positive influence on the growth of the sales in the Italian sports betting market; and on the other hand, has impacted on a series of structural factors in the sector - entry barriers, number of competitors, geographical opening of the market, levels of pricing, average profit margins - in such a way as to determine an increase in industry competition. In particular, use by foreign companies of the electronic distribution channel as a 'mode of entry' into different geographical markets is causing the development of competition that goes beyond national borders, reducing the strongly domestic oligopolistic structure that has always characterized the Italian sports betting industry.
\end{abstract}

Keywords: E-Commerce, industry competition, regulated market, internet gambling, Italy, sports betting industry

\section{Introduction}

The use of the Internet as a direct sales channel for betting has led to the development of a new industry, that of Internet gambling. The birth of this industry took place at the end of the 1990s, thanks to a strong increase in web use worldwide and the introduction of specific software programs for on-line gambling (Wood \& Williams, 2007). Gamblers quickly showed their appreciation for the advantages of Internet betting, giving rise to a market characterized by the specific competitive dynamics.

For a long time, however, on-line bets had been placed on illegal or otherwise unregulated markets. The State legal systems, which normally reserves for gambling a different treatment compared to that of general economic activities to ensure a strong public control over the sale of gambling products (Sirianni, 2012), had in fact mainly used a non-interventionist approach, or have prohibited the majority of Internet betting (H2 Gambling Capital, 2013; Gainsbury \& Wood, 2011; Rose, 2006). Only more recently, several States - including Italy - have legalized many types of on-line betting, favoring the emergence of numerous regulated Internet gambling markets (Fidone \& Linguiti, 2013; Williams, Wood, \& Parke, 2012).

More specifically, in the Italian market, under the 'Bersani decree' of 2006 and the subsequent 'Abruzzo decree' of 2009, the 'Agency of Customs and Monopoly' (Agenzia delle Dogane e dei Monopoli), the regulating body of the Italian gambling sector, has issued a series of regulations for the disciplining of on-line gambling, which has 
allowed players to access via the Internet all types of betting already provided for through the physical distribution network (except in the case where the intrinsic characteristics of the game prevented the use of the digital distribution channel). These regulations have also affirmed a state-controlled management model of Internet gambling - the methods of access to the market and the gambling rules are always defined and monitored by public authorities - but characterized by a more open approach to competition than in the past (Mataluni, 2013). This has meant that even for a highly regulated market such as that of gambling, some typical effects of the use of Internet technologies on competition were verified.

In this regard, the economic-managerial literature highlighted that the increase in the level of penetration of the Internet and the development of e-commerce have caused profound changes in the sector structure and the level of efficiency in many industrial and service markets. Most of the studies focused on the analysis of the impact of e-commerce on price levels at the sector level. This was to verify, through empirical research, whether, simplifying and making the consumer purchase process cheaper, electronic markets could increase efficiency by promoting price transparency (Bakos et al., 2005), enhancing, therefore, price competition, in agreement with the economic models of perfect competition (Lal \& Sarvary, 1999). The results of these studies, as described below, although not unequivocal, mainly confirm the greater price efficiency of e-commerce compared to the more traditional sales network.

However, if we want to fully assess the influence of the Internet on industry competition, we must consider, as noted (Wang \& Zhang, 2015, p. 72) that the price, albeit very important, is "only one perspective of competition and does not reflect the change in the industrial structure".

In this regard, Porter $(2001$, p. 66$)$ in his study on the strategies that companies should adopt in relation to the diffusion of the Internet, describes, through the five forces framework, the different aspects to consider in order to evaluate more fully "how the Internet influences industry structure". He points out, alongside the already reported trend towards a 'migration towards a competition in price', other possible changes in the structural factors of the sector - entry barriers, number of competitors, market size - induced by Internet technologies. Porter, while pointing out that the expected changes, considered as a whole, suggest an increase in the level of industry competition, notes that "it would be a mistake to draw a general conclusion on the impact of the Internet on long-term industry profitability; each industry is affected in different ways", opening up the relevance of research works that investigates this issue in the context of different industries. It is therefore interesting to examine how Internet gambling has affected overall the structural characteristics and the efficiency of the gambling market, also because this aspect has not yet been sufficiently analyzed in managerial studies.

The general objective of this research, then, is to analyze the influence of e-commerce in changing industrial structure and competition in the Italian regulated sports betting market.

The decision to analyze this type of sector is linked to its particular characteristics. As already highlighted, the gambling sector has always been characterized by the need to ensure a strong public control over its business activities. This is to protect consumers from illegal gambling and the risk of pathological gambling, as well as allowing the State to exploit the tax revenues from the sale of gambling products (Sirianni, 2012). Therefore, the gambling sector is one of the most regulated sectors and it is useful to examine if and how in these types of sectors the Internet has influenced the industrial structure.

The choice of studying the Italian sports betting market, on the other hand, is linked to the maturity achieved by this market. As observed (Kaufmann \& Walden, 2014, 11) "as electronic commerce matures, firms will exhibit economically predictable behaviors and abide by well-established economic rules". In other words, in order to understand more fully the influence of Internet technologies on the industry structure and competition, it is necessary to wait for the time necessary for the effects of the change to become apparent. The maturity of the Italian market is the effect of a process of legalization of on-line sports betting that started more than 10 years ago. For this type of gambling Italian consumers have shown an appreciation for the possibility of making bets via the Internet. This has caused a continuous shift of their purchasing behavior from the traditional sales channel, to the digital one. Elaborating the market data, it is possible to highlight in this regard that in 2017 the total on-line amount wagered in sports bets has surpassed the total amount wagered achieved through the land based network. This has contributed to creating an on-line gambling sector among the most developed and consolidated in the world. In fact, the data shows that in 2017 the total on-line wagered amount reached almost 6.5 billion euros, six times the value recorded ten years earlier (Agency of Customs and Monopoly, 2017a; 2017b).

\section{Literature Review}

The development of the Internet has led to significant changes in the relationship between firms and customers, 
"either directly, through e-commerce actions, or indirectly, making previously rare and expensive information interactivity available" (Collesei, Casarin, \& Vescovi, 2001, p. 33). The possibility of reaching the consumer through a direct electronic distribution channel has caused a process of commercial disintermediation that has had a clear impact on the industry structure and on competition in numerous sectors. Various studies in the field of economic and management science have therefore analyzed the transformations induced on competition by the introduction of Internet technologies in different industries. In particular, the attention of the researchers has been focused on the study of the impact of the Internet on industry price competition. They have tried to verify the hypothesis that the low research costs associated with e-commerce lead to a reduction in prices at the level of marginal costs, for perfectly homogeneous products, and a reduction in prices for differentiated products (Bakos, 1997; Alba et al., 1997). Their analyzes then examined, through empirical research, whether prices of specific products and services sold through the on-line distribution channel are, as assumed, lower on average than the brick-and-mortar retailers and if there is less 'price dispersion' - defined as the distribution of prices (such as range and standard deviation) of an item with the same measured characteristics across sellers of the item at a given point in time (Pan, Ratchford, \& Shankar, 2004) - compared to that which characterizes traditional retailers. Most of this research compared the prices of fairly homogeneous products, such as books, video and music CDs and software (Brynijolfsson \& Smith, 2000; Lee \& Gosain, 2000; Friberg, Ganslandt, \& Sandström, 2000), car sales services (Morton, Zettelmeyer, \& Silva-Risso, 2001; Zettelmeijer, Morton, \& Silva-Risso, 2006) and life insurance (Brown \& Goolsbee, 2002), highlighted in line with the theoretical assumptions that the prices charged on average through the on-line distribution channel are lower than those adopted by the bricks-and-mortar retailers. Some studies, still concerning products such as books, CDs and software (Sabate, Cañabate, Cobo, \& García, 2009; Bailey, 1998; Clay, Krishnan, Wolff, \& Fernandes, 2002; Ancarani \& Shankar, 2004), have instead found that on-line prices on average are higher or are at least at the same level as those that are practiced by physical stores. In this regard, some scholars (Pan, Ratchford, \& Shankar, 2004; Li \& Tang, 2011) reported that the results of this second group of research, that were not in line with the theoretical hypotheses, may have been conditioned by the not complete maturity of the markets analyzed or the different degree of homogeneity of the products examined.

The results shown, even if not always consistent, mainly confirm the greater price efficiency of e-commerce compared to the physical distribution channel.

Further potential effects of the spread of Internet technologies on the industry structure have concerned the impact of e-commerce on the barriers to entry and the consequent effects on the level of competition and profitability of the markets. In this regard, as observed (Goldmanis, Hortacsu, Syverson, \& Emre, 2010, p. 674), "while there is an empirical literature investigating the advent and diffusion of e-commerce on prices, little has been done regarding the market structure", especially regarding the number or type of competitors that operate in the industry and the change of their market shares.

Taking this in to account, Porter (2001), by analyzing the Internet influences on industry structure, has hypothesized that the diffusion of web technologies should favor a reduction of the entry barriers, facilitating the arrival of newcomer firms, with a potential negative impact on the level of concentration and the profit margins in the sector.

The studies that have dealt with these issues in a broad sense, however, have shown different results in relation to the type of industries studied and the parameters used to measure the variation of industrial competition. For example, research has shown that both the barriers to entry and the entry of a fairly large number of new companies have been verified in some sectors in which is common the use of Internet technologies and e-commerce (Gropp \& Kok, 2017; Bakos et al., 2005), causing a general reduction in sales concentration levels and average profits, in line with Porter's hypotheses.

Other studies (Wang \& Zhang, 2015; Goldmanis et al., 2010), instead, have shown how the Internet technologies have favored, in specific sectors, industry consolidation processes with growth effects both in terms of industry concentration ratios and profit margins. In this regard Wang and Zhang $(2015$, p. 79$)$ point out that their research carried out in certain types of sectors (manufacturing, wholesale, retail and services) showed results that were "contrary to the widely held beliefs they Internet increases industry competition". These authors report that the results of their investigations support the winner-take-all-structure of the Internet economy proposed by Frank and Cook (1996), based on the hypothesis that the trends of social and technological change in the modern economy could favor, especially in the web markets where the network effects and customer-to-customer communication are central for business strategy, the statement that few win the competition.

In summary, it is difficult to generalize the impact of the Internet on industry competition, because each industry 
can be affected by these different features in relation to their different structural characteristics. This makes it important to study the dynamics underlying the changes induced by the spread of Internet technologies and of e-commerce, also because, as observed (Wang \& Zhang, 2015, p. 80), "the effect of the Internet on industry competition has been widely discussed, but no empirical evidence based on overall industry change is available".

This is also true for the gambling industry. Researches that have examined the socio-economic consequences of the spread of on-line gambling have done so mainly by focusing on specific issues. For example, some studies have focused their attention on the examination of regulatory frameworks in the various countries, to help public institutions in the implementation of gambling policies and companies to formulate appropriate on-line gambling responses (Kairouz, Monson, \& Arsenault, 2018; Ansalone \& Cestari, 2013; Mataluni, 2013; Pandimiglio \& Spallone, 2012; Gainsbury \& Wood, 2011; Coryn, Fijnaut, \& Littler, 2008; Rose, 2006; Eadington, 2004; Sbordoni, 2010). A series of research works in the economic-managerial field that were carried out, on the other hand, has deepened, under different aspects, the impact of Internet gambling on consumer behavior and on marketing strategies (Calvosa, 2016; Gainsbury et al., 2015; Ozuem \& Prasad, 2015; Wiebe, 2008; Wood, Williams, \& Lawton, 2007; Jolley, Mizerski, \& Olaru, 2006; Woolley, 2003; Brindley, 1999). An extensive literature, moreover, has focused on the study of the social impact and the risks associated with the diffusion of Internet gambling (amongs others: Chóliz, 2016; Gainsbury, Parke, \& Suhonen, 2013; Yani-de-Soriano, Javed, \& Yousafzai, 2012; Griffiths, Wood, \& Parke, 2009; Griffiths \& Parke, 2002; Griffiths, 1999). Even the research that has analyzed in a broad sense the major economic trends and issues associated with Internet gambling (Gainsbury, 2012; Williams et al., 2012; Pilling \& Bartlett, 2012; Gandolfo \& De Bonis, 2011; Wood \& Williams, 2007), did not systematically investigate how the total of the structural changes in the sector induced by e-commerce is impacting on industry competition.

\section{Aims of the Study and Methodology}

As described in the introduction, the general object of this study is to analyze the influence of e-commerce in changing industry structure and competition in the Italian regulated sports betting market. In keeping with the aspects discussed above, this object has been articulated into some specific aims presented as follows:

To analyze the influence of the legalization of Internet gambling on market size in terms of sales and on the consumer behavior in the Italian sports betting market;

To analyze the influence of the legalization of Internet gambling on the barriers to entry and the access of new gambling operators in the Italian sports betting market;

To analyze the influence of the legalization of Internet gambling on the industry concentration ratio in the Italian sports betting market;

To measure how, in the Italian sports betting market, the average prices have changed over time after the legalization of Internet gambling;

To measure how, in the Italian sports betting market, the industry average profit margins have changed over time after the legalization of Internet gambling.

From a methodological point of view, firstly the information from a series of secondary sources (academic journals, market research, specialized reviews, gambling press agencies, Italian Ministry of Economy and Finance, Istat - the Italian National Institute for Statistics -, Censis - Center of Study in Social Investiments) was used in order to examine the main changes that have affected the sports betting industry in Italy. In particular, the official market data provided by the Agency of Customs and Monopoly and by the 'Journalistic agency on the gambling market' (Agimeg) have been collected and processed for the years between 2006 and 2017, thus carrying out an analysis of a longitudinal type on the investigated aspects.

Secondly, the data and information collected through specific empirical investigations were used. Specifically:

1. in order to deepen the study of the business models adopted by the companies operating in the Italian regulated sports betting market after the legalization of Internet gambling, an in-depth study of the competitive strategies was carried out of companies that, in terms of amount wagered, represents more than 90 percent of the sports betting market in Italy in 2017. For each of the companies examined it was analyzed: 1) the information reported on the company sites; 2) official data per operator (type of gambling concession, market shares, etc.) provided by the Agency of Customs and Monopoly and by Agimeg; 3) data coming from a series of secondary sources (specialized magazines, market research, etc.);

2. in order to analyze the impact on gambling behavior because of the introduction of Internet betting, an 
empirical investigation was carried out on a sample of Italian consumers. The investigation was realised through the administration of a questionnaire addressed to the universe of clients who make sports bets on legal gambling websites in Italy. The questionnaire was administered through the CAWI method, during an 8-month period (from 30 August 2014 to 30 April 2015). At the end of the survey period the questionnaires compiled correctly numbered 263 .

\section{Results and Discussion}

\subsection{The Birth and Development of the Italian Regulated on-Line Sports Betting Industry}

The use of the Internet as a gambling distribution channel has developed in Italy since the 90 s, when different unauthorized foreign gambling operators entered the Italian gambling market through various web sites dedicated to on-line gambling. As noted (Mataluni, 2013, pp. 131-132), in deed, at the beginning of the new millennium "to stringent regulations dictated for physical gambling was opposed a total liberalization, due to the absence of regulation, in the on-line sector. [...] Many foreign operators have come to the Italian regulated market and have managed to enter through a window to the on-line world, thus accessing a national market that otherwise would have been complicated if not impossible to reach". The possibility of providing bets via the Internet across national borders had therefore contributed to the development of an unauthorized cross-border market, thanks to the tolerance of the state authorities and the lack of effective application of existing regulatory frameworks (Ansalone \& Cestari, 2013).

To remedy the development of an uncontrolled market, in 2002 the Italian legislators approved the rules that experimentally launched Internet gambling (Sbordoni, 2010). In 2006 a new disciplines were issued for the provision of on-line gambling, thus establishing the ban on on-line cross-border sales by gambling operators without public authorization. This also caused the obscuring of numerous foreign gambling websites, which in many cases had initiated forms of litigation for the violation of the principles of the European Common Market (Bonanni, 2008). The Bersani Decree of 2006 intervened to solve many of the problems of coordination between the EU and national Italian law in the field of on-line gambling. This decree, aimed at "countering the spread of irregular and illegal gaming, tax evasion and avoidance in the the gambling industry, as well as ensuring the protection of the gambler", represented a turning point that helped to create a regulated gambling industry among the most developed and consolidated in the world.

By limiting analysis to the rules that have affected the sports betting industry, it is firstly possible to point out that the decree in question provides for the issuing of a call for tenders, for the allocation of new gambling licenses. These were joined to those held by betting agencies, which were until then authorized exclusively to the intermediation of sports betting in Italy. In particular, operators assigned the new licenses from the Autonomous Body Administering State Monopolies (now Agency of Customs and Monopoly), and were authorized to sell the games through two new types of stores with distinct characteristics, the 'betting shops' and the 'corners', which allowed the development of a capillary land based network. In addition, the Bersani Decree had organically regulated Internet gambling, defining a new authorization model that has opened the Italian legal market to foreign gambling operators that have in their own countries a license that enables them to exercise their legal betting activities. Many of them, as detailed below, thanks to the release of a specific gambling license, have exploited the potential of the web to replicate their offer of betting services, already proposed in other countries, in the Italian gambling regulated market (Mataluni, 2013).

\subsection{Internet Gambling and Industry Structure: The Influence on Market Sales and on the Consumer Behavior In the Italian Sports Betting Market}

In line with the aims of this study, the influence of the legalization of Internet gambling on market size in terms of sales and on consumer behavior in the Italian sports betting market was first analyzed.

To introduce the analysis, it is useful to provide an overview of the growth of the total amount wagered (Note 1) in the sports betting sector in Italy in the period from 2006 (the year of issue of the Bersani Decree) to 2017.

Figure 1 shows, firstly, the graph of the total amount wagered in the sports betting industry in Italy between the years of 2006-2017. The figure shows that it had almost quintupled in nominal terms, against a continuous growth in sales that had led the sector to exceed, in 2017, 12 billion euro of bets placed. 


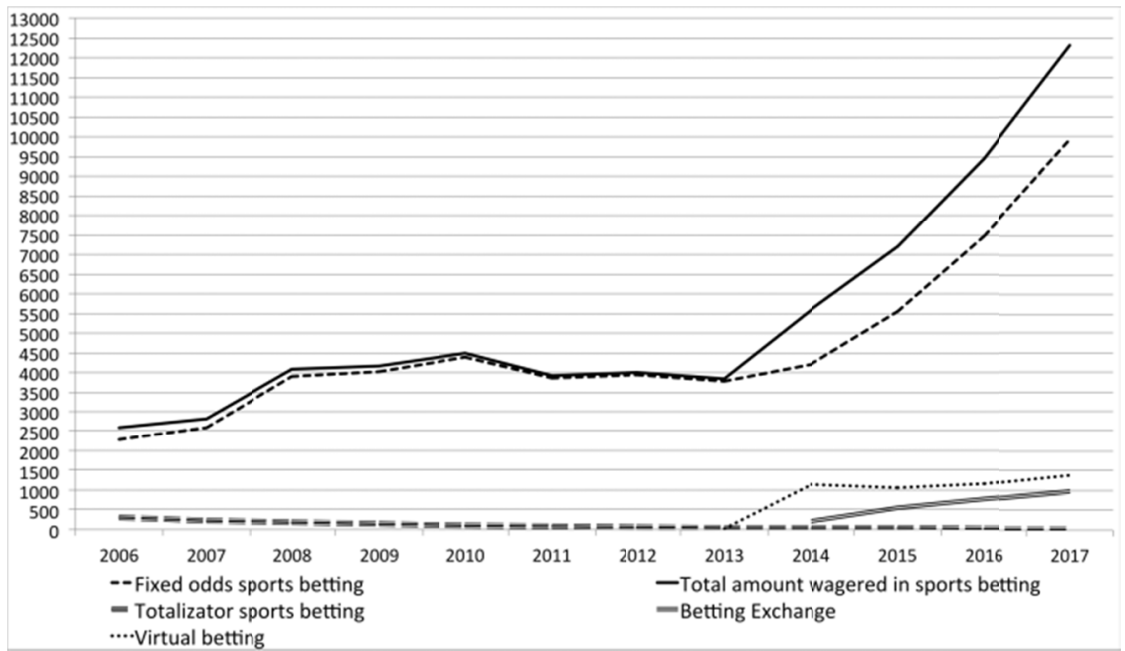

Figure 1. Total amount wagered in Sports betting industry and amount wagered for sports betting type - 'Fixed odds sports betting', 'Totalizator sports betting', 'Virtual betting' and 'Betting Exchange' -. Italian regulated market. Years 2006-2017 (millions of euros).

Source: our processing of data from Agency of Customs and Monopoly.

The total amount wagered is the sum of amount wagered by various legal gambling categories linked to the sports, whose trends are also graphically represented in Figure 1. Specifically, the main segment in terms of sales is that related to the 'fixed odds sports betting' which, with a wagered amount reached almost 10 billion euros in 2017. This represents more than 80 percent of the total amount wagered in the sports betting market in Italy. The fixed odds bets are those for which the players are aware of the amount of possible winnings at the time of the bet being placed. It is pre-defined at the time of purchase by multiplying the odds of the sports event defined by the gambling operator with the stake (Cestari, 2013). This type of betting was legalized in Italy in 1998 to counter the phenomenon of clandestine betting, that facilitated the development of an illegal gambling market (Sirianni, 2012). Over time, the fixed odds bets recorded an extremely strong sales growth, thus replacing the 'totalizator sports betting', which had represented for decades the only type of legal betting in sports-based games in Italy. Totalizator sports bets are those for which, at the time of the bet, it is not possible to know the amount of any winnings earned. The prize money, in fact, at the end of the sports event is subdivided, net of taxes due to the State and of the quota due for gambling operators, among all those who have bet on the winning prediction (Cestari, 2013). As shown in Figure 1, the total amount wagered in this category of game - which includes Totocalcio, Totogol, Totosei and Totobingol -, has recorded a steady decrease that in 2017 and have led to this type of bet almost disappearing from the Italian gambling regulated market.

In addition to the two types of betting just described, in Figure 1 the trends of the total amount wagered of two other innovative types of fixed odds bets linked to the ability to guess the result of sporting events are illustrated graphically.

The first category of game is that of 'virtual sports betting'. This type of bet is based on simulated computer events that reconstruct the highlights of sporting events. One of the main differences between the classic sports betting and the virtual ones consists in the duration of the sports event. A simulated sports event lasting only a few minutes. This form of betting, legalized from 2013, quickly established itself in Italy, reaching, as shown by Figure 1, an amount wagered almost equal to 1.4 billion euros.

The second category was introduced into the regulated market in April 2014. It is that of the 'Betting exchange'. It is defined by the Agency of Customs and Monopoly as a fixed odds sports betting mode where player can play the role of bettor or banker and the licensed operator acts as an intermediary, thus merely putting in contact, through the digital platform and anonymously, individual bettors. The odds are, therefore, established by the players themselves and the concession holder retains a margin from the winnings as a commission. The Betting exchange represents an important innovation in the field of public gambling in Italy. This being because it is a form of betting classified as "peer to peer" that replaces the traditional collection based on betting shops, by direct interaction via the Internet between players (Pandimiglio \& Spallone, 2012). The role of pure intermediary of the concessionaire means that despite, as shown in Figure 1, the total amount wagered has quickly reached almost one billion euro, the pay-out (the sum that returns to the players in the form of winnings) of that game is 
the highest of the legal forms of gambling in Italy.

The description of the types of sports betting in Italy and the related economic data allows a better understanding of the development of Internet betting and its influence on the whole market size in terms of sales. An initial analysis can be carried out by comparing the trends of total amount wagered in the regulated sports betting industry in Italy (realized through both the Internet and the land-based network), with that achieved only via the Internet (Figure 2).

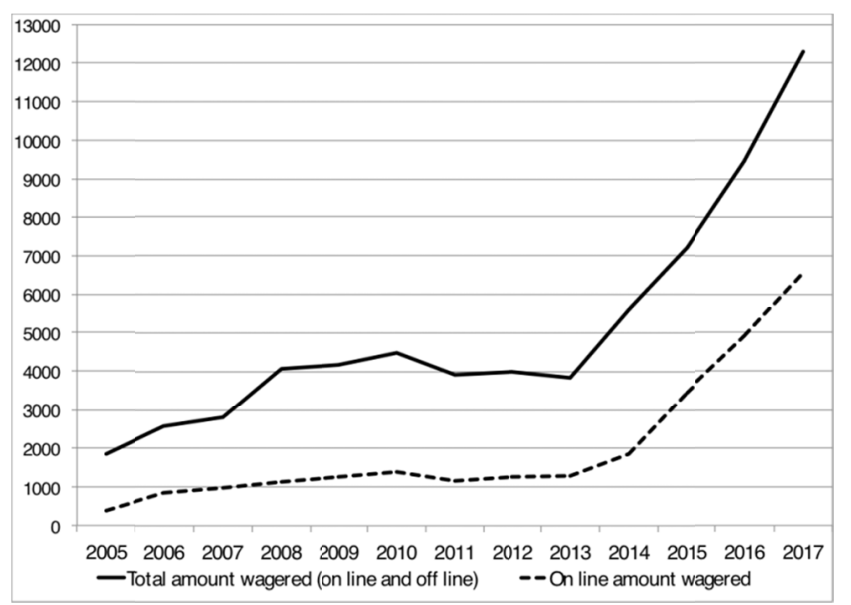

Figure 2. Total amount wagered in sports betting (on-line e land based) and total amount wagered in on-line sports betting. Italian regulated market. Years 2005-2017 (millions of euros).

Source: our processing of data from the Agency of Customs and Monopoly.

Figure 2 shows a similar trend of curves that describe the two levels of total amount wagered, suggesting a correlation between the trend of on-line sales and the growth in overall sales in the sector. This indicates that the expansion of the market in terms of sales in Italy is significantly influenced by an increase in on-line sales. The total on-line amount wagered in 2017 reached almost 6.5 billion euros, following a steady growth - excluding the period 2010-2013 - characterized by annual double-digit growth rates.

In general, we can state that the success of on-line gambling is a consequence of the increase in Internet penetration around the world, as well as some benefits connected to on-line consumer behavior. In this regard, in keeping with the aim to analyze the influence of e-commerce on the consumer behavior in the Italian sports betting market - as described in the third paragraph in which the research methodology was analyzed - an exploratory survey on a sample of customers (n. 263) was carried out in the Italian regulated market in 2015, which made it possible to identify the main benefits perceived by Italian gamblers in the use of the digital channel for the purchase of sports bets to replace the physical one. In the Table 1 the results of this survey are summarized.

Table 1. The perceived customer benefits of Internet gambling vs. gambling at a land-based venue. Italian regulated on-line sports betting market (n: 263).

Advantage types Specific benefits

Advantage of time

To gamble outsides traditional betting shop opening hours

Quality of the consumer experience

High speed of game play

Comfort

Lack of crowd and queuing

To play 'on the move' (via smartphone, tablet, etc.)

Avoid mixing with indesirable land-based clients

Privacy (to play without being seen by others)

Range of consumer choice

More variety of sporting events to bet on

Quick and easy gambling websites comparison

More information

More information to make the best informed bet

Details of bets made over time

Economic convenience

Higher potential wins

Quick and easy odds comparison

Source: our elaboration. 
From the Table it emerges first that in the sports betting sector the Internet allows a considerable reduction of the space-time constraints that characterize the relationship between gambling operators and customers managed through physical betting shops. Through the use of a digital channel for access to gamblling, indeed, consumers perceive significant advantages in terms of time, as they reduce betting time and can more easily make 'last minute' bets, as well as play beyond the traditional opening hours of betting shops. There are also important advantages of quality of consumer experience, connected to the possibility of avoiding crowds and queues, and the meeting of undesirable clients, and benefits in terms of privacy, additional to being able to bet comfortably through mobile devices.

Continued reading of Table 1, shows that Italian players also appreciate advantages in terms of increased information and choice alternatives offered by the digital distribution channel. Internet access, in fact, has considerably increased the level of information available to the consumer. This both in terms of better knowledge of the gambling operators providing the service and the range of services offered, not to mention a greater availability of data - obtained through access to on-line discussion forums and betting tracking software - this being useful for improving the effectiveness of bets and thus increasing the odds of winning.

Finally, the decision to purchase betting services via the Internet is also encouraged by incentives of an economic nature. As will be explored later, the direct sale of gambling services to the consumer, without the intermediation of the physical network, in fact allows on-line gambling operators to benefit from cost savings that can be partially passed on to the customer in the form of lower costs of services purchased and better pay-out rates.

The increasing popularity of Italian bettors towards on-line sports betting has had the effect of shifting a considerable part of gambling market from the physical channel - the land based network - to a digital channel. Figure 3 shows, in this regard, the graph of the trend of percentage incidence of the on-line amount wagered on the total amount wagered (on-line and land based) in the Italian sports betting industry from 2005 to 2017.

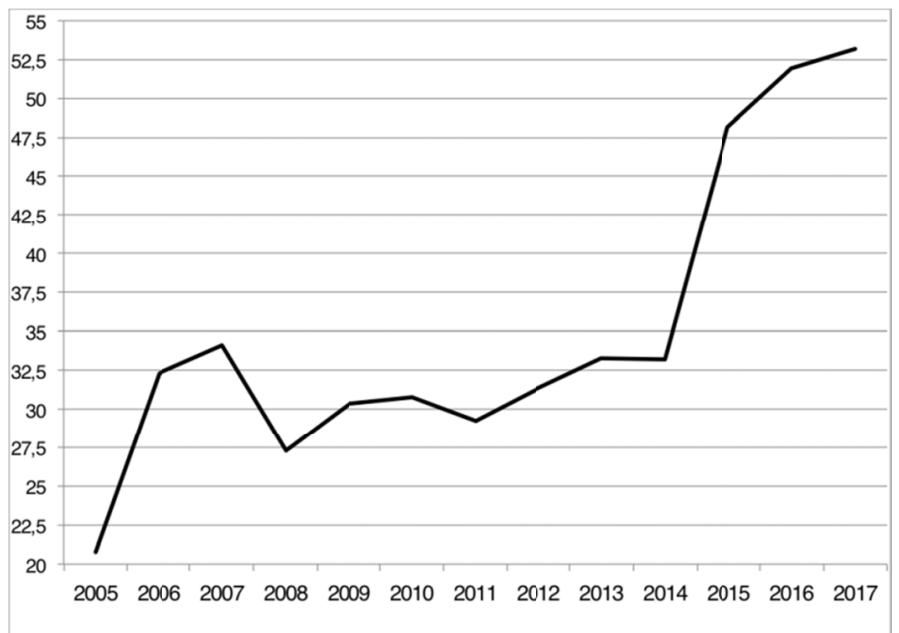

Figure 3. Percentage incidence of the on-line amount wagered in respect to the total amount wagered (on-line and land based). Italian regulated sports betting market. Years 2005-2017

Source: our processing of data from Agency of Customs and Monopoly.

The graph shows that over the period considered the incidence of on-line gambling has grown from just over 20 per cent to more than 50 per cent in 2017. More specifically, there have been three different stages of development of Internet betting in Italy: first phase - 2005-2007 - characterized by a strong increase in the weight of purchases made through the Internet, following the obscuring of 1,500 gambling websites, mainly foreign, which did not have the ministerial authorization for the sale of sports bets in Italy. This blackout provoked a return to the regulated market of a high volume of betting on the Internet (Bonanni, 2008); a second phase - 2008-2014 - during which the weight of on-line amount wagered was kept stable (around 30 per cent); a third phase - 2015-2017 - in which there was a decisive acceleration of the sale of sports betting via the Internet. This was especially in relation to the increased popularity of gaming modes through mobile devices and, as discussed below, to gambling offers particularly convenient provided by foreign companies that had recently entered into the Italian regulated gambling market. 
4.3 Internet Gambling and Industry Structure: The Influence on the Barriers to Entry and the Access of New Gambling Operators in the Italian Sports Betting Market

An other aim of this study was to analyze the influence of the legalization of Internet gambling on the barriers to entry and the access of new gambling operators in the Italian sports betting market.

To study this aspect, it is appropriate to analyze separately the main legal types of sports betting in Italy - fixed odds sports betting, virtual betting and betting exchange - as characterized by different competitive dynamics, also in relation to the different times of introduction in the market (the latest two types of bets were legalized, respectively, in 2013 and 2014).

As for the fixed odds sports betting - which, as already highlighted, in 2017 represented more than 80 percent of the total amounts wagered in Italy in sports bets - an in-depth study of the competitive strategies of companies that, in terms of amount wagered, represents more than 90 percent of the market in Italy was carried out (as described in the third paragraph in which the research methodology was examined).

Analysis allowed first of all to study the trend of the weight of amounts wagered generated by Italian companies compared to that of foreign companies in the years 2009-2017 (Figure 4). This made it possible to highlight that the on-line bets and the regulated opening process of the market has facilitated entry into the sector of foreign newcomers who have acquired market leadership. From Figure 4 it emerges that the incidence of total amounts wagered generated by foreign companies, on the overall one of sports betting market in Italy, has gone from just under 14 percent in 2009, to almost 70 percent in 2017. These companies only entered the Italian market from 2006, under the new rules introduced with the Bersani decree and leveraging the on-line sales channel.

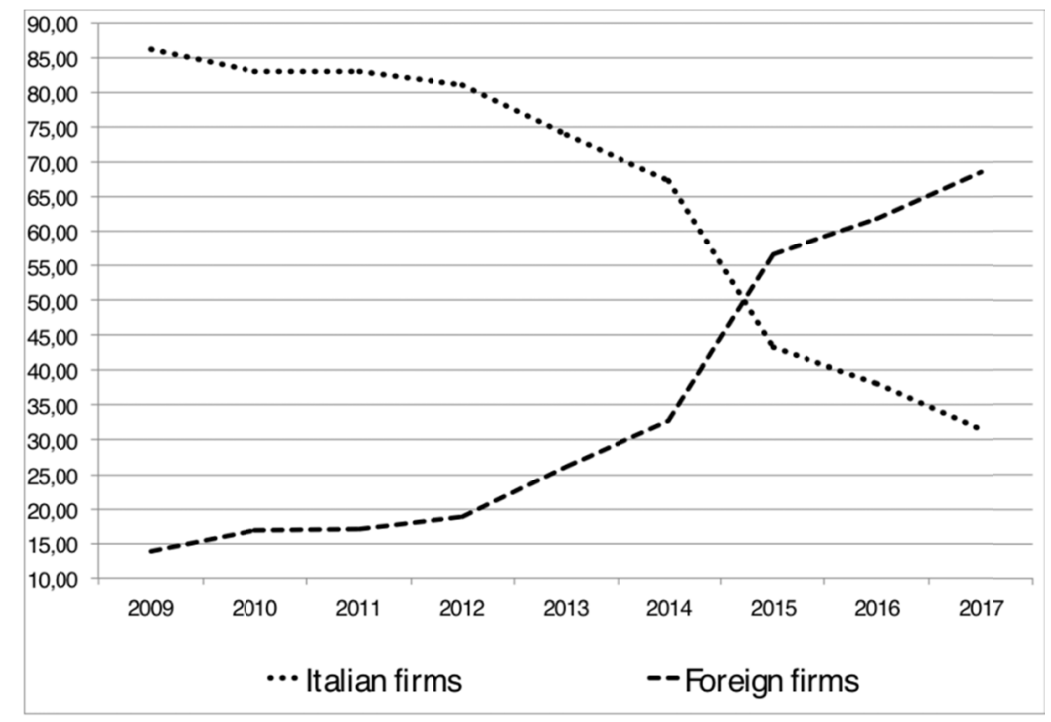

Figure 4. Italian firms vs. foreign firms: incidence on total amount wagered. Fixed odds sports betting. Italian regulated market. Years 2009-2017 (percentage data).

Note: The incidence was calculated considering more than 90 percent of the gambling operators in the fixed odds sports betting market, in terms of amount wagered.

Source: our processing of data from Agency of Customs and Monopoly and Agimeg.

It is also important to highlight that if the analysis is focused only on the on-line sports betting market, the data process shows that foreign companies control more than 75 per cent of the wagered amounts in 2017 and almost 70 per cent of Gross Gambling Revenue.

The empirical analysis carried out has also allowed us to take into account some interesting considerations on the different business approaches adopted in the sector.

The Italian companies, which in 2009 controlled more than 85 per cent of total amount wagered and which saw their cumulative market share reduced to around 32 per cent in 2017, are almost entirely incumbent companies (Note 2). These have been operating for a long time in Italy through the physical distribution network. Reference in particular is made to Snai, Lottomatica and Sisal which, until 2014, were the leading companies in the market. 
Even though these companies have lost their leadership in terms of amount wagered, in 2017 they still hold the first, third and fifth positions in terms of Gross Gambling Revenue, this in addition to the first, second and fourth positions in the retail betting market respectively. The Italian companies operate in the public gambling sector mainly in the domestic market and with a diversified range of gaming (Note 3). These take care of sales, as well as sports betting, of many types of games (lotteries, lotto, slot machines, bingo, horse betting, on-line poker, etc.) (Note 4). Italian companies almost exclusively adopt a multi-channel business approach, of which the use of the Internet has enabled to reach the customers trough the digital sales channel, complementary to the physical one, and to offer to the player the possibility to choose how to access bets in relation to the occasions of use (Note 5).

Foreign companies, on the other hand, have actually been able to enter the Italian regulated market through the on-line distribution channel. Unlike Italian companies, these organizations operate in several geographical areas, and are mainly focused on the sports betting market. They have exploited the effects of the regulated opening process of the market and the potential of the web to replicate in the Italian gambling market their range of gambling products already provided in other countries. More specifically, it is possible to identify two different business approaches adopted by these foreign companies.

The first approach is that that is used by Internet pure players. For these companies, the process of commercial disintermediation, facilitated by the Internet gambling liberalization, has allowed them to overcome the difficult barriers blocking entry into the Italian sector, consisting of the huge investments to be sustained in managing a physical distribution network which is necessary to reach a large number of consumers. In 2017, the information processed by us from the market data made it possible to highlight that the foreign Internet pure players (among the main ones: Bet365, William Hill, Bwin) controlled about 30 percent of the total amount wagered in the Italian sports betting industry. If analysis focuses only on the Internet sports betting segment, the empirical investigation carried out also shows that these companies control, in 2017, more than half of on-line amounts wagered.

A second business approach adopted by foreign companies is that in which, in addition to providing gambling services via the Internet, they have created a physical distribution network in Italy, thus adopting a multi-channel approach. This approach is used by two groups of companies that have chosen different entry strategies.

A first group - which comprises Eurobet and Intralot, for example - includes some gambling operators that, since the early 2000s, have operated in the Italian market through websites dedicated to sports betting, exploiting the absence of a specific regulation for Internet Gambling. These companies have requested and obtained, from 2006, legal gambling licenses issued by the Autonomous Body Administering State Monopolies following the process of opening up to foreign companies realized with the Bersani Decree, deciding therefore to subject their activities to Italian regulations and taxation. They therefore have taken advantage of the customer base already acquired in the on-line sector to propose their gambling offers both through authorized websites, and through the opening of a network of betting shops, thus adopting a multi-channelled approach, whereby sales tend to be distributed between the physical and digital distribution channels.

A second group of foreign companies, on the other hand, entered the Italian regulated market in 2015, after having redressed its position with respect to the legislation dictated by the Agency of Customs and Monopoly. We refer to foreign companies that managed "Data Transmission Centers". These centers are commercial establishments that have been operating for years in the sports betting market in Italy, taking advantage of some regulatory provisions in Europe. They acted as Internet points, transmitting on-line to foreign companies the sports betting proposals received from Italian customers, despite the Italian legislation that did not allow them to carry out brokerage activities as they lack the necessary authorization required by Italian law (Mataluni, 2013). Most of these centers have legalized their position since 2015, adhering to an amnesty that has included their activities within the system of authorization of the Agency of Customs and Monopoly, with the related effects of a fiscal nature on sales. This group includes operators such as Sks 365, GoldBet and Betaland who, after legalizing their position, now collect sports betting either through an extended retail network or via authorized websites.

The multichannel foreign companies, both of the first and of the second group, have almost quadrupled the weight of their total amounts wagered in the Italian regulated market, having grown from just over 10 percent in 2009 to around 38 percent in 2017.

Turning to the analysis of the other two legal types of gambling in the Italian sports betting market, which together represent approximately one fifth of the total amounts wagered, it is possible to highlight the very important role played by foreign companies.

Specifically, for Virtual betting the sales, which began in 2013, exceeded 1,400 million euros in terms of total 
amount wagered in 2017. In this type of gambling, foreign companies control more than 55 percent of the market. In particular, companies that have adopted a multi-channel approach, both foreign and Italian, play a central role - the leader is GoldBet, which is a foreign company that entered the regulated market following the legalization of Data Transfer Centers - as more than 90 percent of the total amount wagered is collected through the land based network, whereas Internet pure players hold marginal positions.

Also for the Betting exchange the market is controlled by foreign operators. As already pointed out, this innovative form of fixed odds sports betting provides that the franchisee acts as an intermediary, thus limiting itself to putting into contact, through the Internet and anonymously, the individual bettors. This type of gambling was created by the foreign group Betfair (a company which introduced the collection in Italy in 2014). This group has an almost monopolistic position in this type of betting, controlling more than 95 per cent of the billion euros collected in 2017. Probably the entry of other operators was limited not only by the technological and market leadership of Betfair, but also by a lesser attractiveness in terms of profits, due to the fact that the pay-out of this type of bet is the highest among all the forms of legal gambling in Italy (given the pure intermediary function of the bookmaker). In fact, in 2017, the Betting exchange returned 99.5 percent of the bet amounts collected in terms of winnings, thus allowing operators to achieve only very low profit margins.

\subsection{Internet Gambling and Industry Structure: The Influence on the Industry Concentration Ratio in the Italian Sports Betting Market}

A further aim of this work was to analyze how the level of industry concentration in the Italian gambling market has changed over time after the legalization of the Internet gambling. The analysis carried out so far has enabled us to highlight how the lowering of barriers into the market, linked to the development of on-line gambling and the regulated market opening process, has led to the entry of new foreign gambling operators who have acquired significant market positions. This suggests that the level of sales concentration should have changed through recent years.

To verify this, the variation of the sales concentration ratio in the fixed odds sports betting market - the main gambling market in the Italian sports betting industry - was analyzed. This type of sports betting is the only one for which it was possible to process sales data for a fairly significant period.

Therefore the industry concentration ratio - calculated as the percentage of the cumulated amount wagered generated by the top five gambling operators of the total amount wagered in the sport betting market in Italy was measured in the decade 2007-2017.

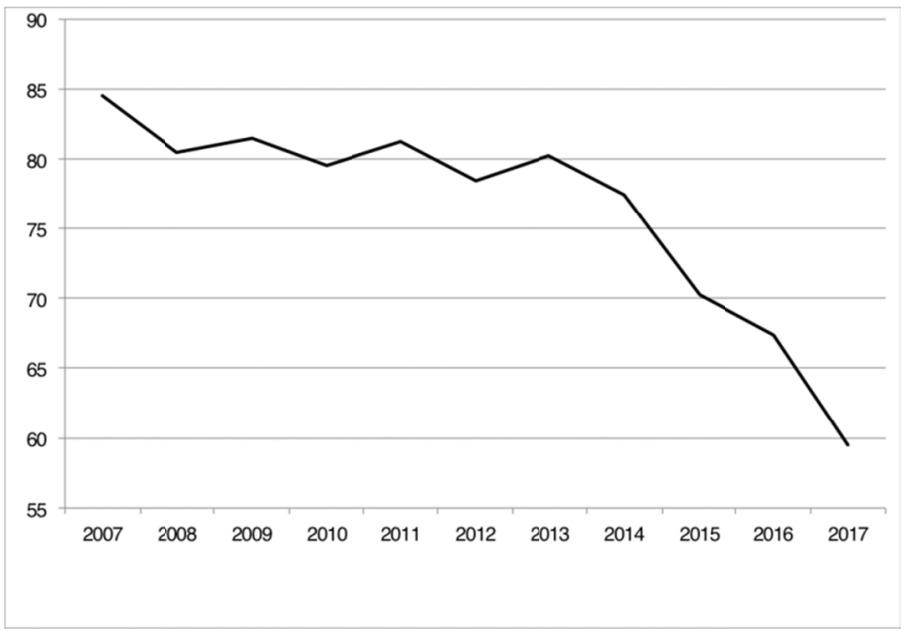

Figure 5. Industry concentration ratio in the Italian fixed odds sports betting market (percentage of amount wagered generated by the top five gambling operators of the total amount wagered). Years 2007-2017

$$
\text { (percentage data). }
$$

Source: our processing of data from Agency of Customs and Monopoly and Agimeg.

As shown in Figure 5, in the period analyzed the concentration ratio rose from extremely high values (almost 85 percent in 2007) to significantly lower values. In particular, since 2014, there had been a more consistent decrease in the concentration level. This led the top five companies in the sector to control less than 60 percent 
of total amounts wagered in 2017, with a relative percentage decrease in the concentration ratio in the period examined equal to 30 percent.

In summary, the access into the market of new foreign companies connected to the development of on-line gambling, initially impacted only marginally on the concentration levels of sales. However in the last four years it seems to be causing very significant changes in the industry, that are reducing the strongly oligopolistic structure that has always characterized the Italian betting industry.

4.5 Internet Gambling and Industry Structure: The Influence on Prices and Profit Margins in the Italian Sports Betting Market

The changes that have occurred in the Italian sports betting industry have caused, as described, significant impact on the industry structure and competition. These changes should have affected the average sales prices of gambling services and profit margins of the gambling operators.

Consistent with the aims of this study, it was measured how, in the Italian sports betting market, the average prices and the industry average profit margins have changed over time after the legalization of Internet gambling.

It has been first been analyzed how the sports betting prices in Italy have changed in the last ten years. In order to make operational this analysis, it was first defined what is meant by the price of a sports bet. Unlike traditional products and services, in fact, there is no equivalent pricing concept for gambling products. In fixed odds betting, the player chooses to bet a certain amount on the possible outcome of a specific sporting event and, only in the case of a win, the gambling operator pays a sum equal to the bet multiplied by the odds associated with the event, which are fixed at the time of the bet.

To establish an indicator of the sports betting price, a criteria has been adopted in a way that has already been used in literature (Simmonds \& Sharp, 1987; Pandimiglio \& Spallone, 2012; Gandolfo \& De Bonis, 2013) that considers the standard unit of a wager equivalent to one euro, defining the price as the part which is not intended to be returned to bettors in the form of winnings (also called pay-out). As noted (Gandolfo \& De Bonis, 2013, p. 15), in fact, the players are informed in advance of the fact that on average in making, a sports bet, they will suffer a loss (equal to the difference between the sums bet and the pay-outs), but since it is a recreational activity for them, "the expected loss is the price that the player is willing to pay (or to acquire the right to the illusion of being able to win, until the moment he knows the official outcome of the game or bet)" (Note 6).

In our definition, therefore, the percentage of the amounts played in a certain period of time not redistributed in winnings can be considered an indicator of the average percentage price for the purchase of sports betting, also called take-out rate.

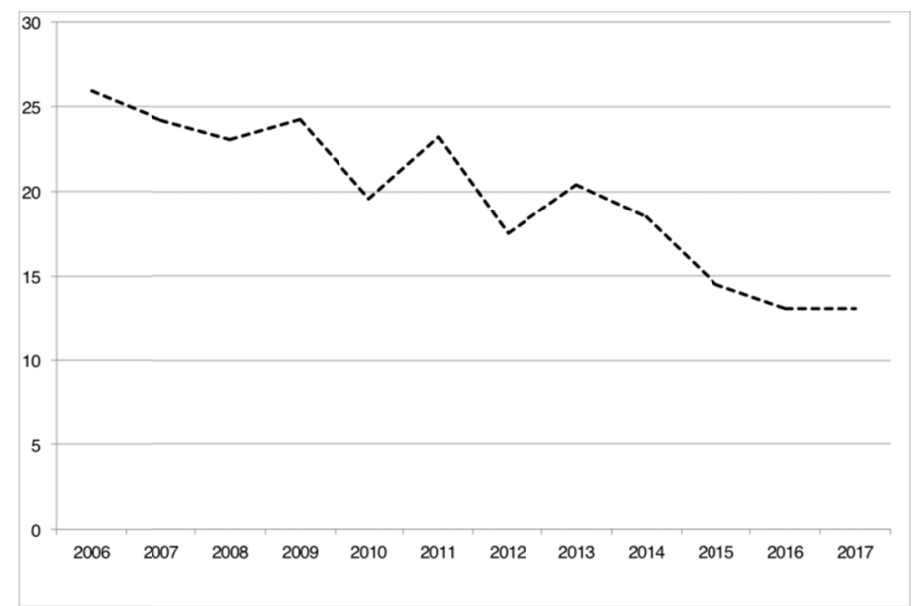

Figure 6. Average percentage price (take-out ratio). Italian regulated sports betting market. Years 2006-2017 Source: our processing of data from Agency of Customs and Monopoly.

Figure 6 shows the trend in the annual take-out rate for sports betting through the years 2006-2017, calculated on the basis of data provided by the Agency of Customs and Monopoly (Note 7). The graph shows that this rate has decreased in the period analyzed by 50 percent (from about 26 percent in 2006 to just over 13 percent in 2017). Therefore, it emerges that the increase in competition was the prerequisite for a significant and continuous decrease in the average sales prices of sports betting in the Italian regulated market.

In order to better understand the impact that on-line gambling has had on price reductions, an in-depth analysis 
was carried out, aimed at measuring the differences in terms of average percentage prices of gambling products sold through the Internet and those sold through the land based network. The result of analysis shows that in the years 2013-2016 the average percentage prices of on-line sports bets remained lower by about 10 percentage points in absolute terms and 40 percentage points in relative terms, compared with the average prices of sports bets sold through betting shops.

The increase of price competition, naturally also impacted on profit margin percentages of companies operating in the sector. In fact, the price of the bet includes the taxes due to the Treasury and the profit of the gambling firms. As prices have been reduced, this part of the sum which, after taxes, goes to remunerate the supply chain operators (gambling operators and distribution points) has also decreased.

Figure 7 shows that the annual average profit margin percentage for every euro bet has in fact decreased from 15 percent in 2006 to 10 percent in 2016. The graph also shows that in some years the profit margin percentage had increased in relation to some changes in taxation that had declined the part of sums destined to the Treasury, much to the benefit of gambling operators.

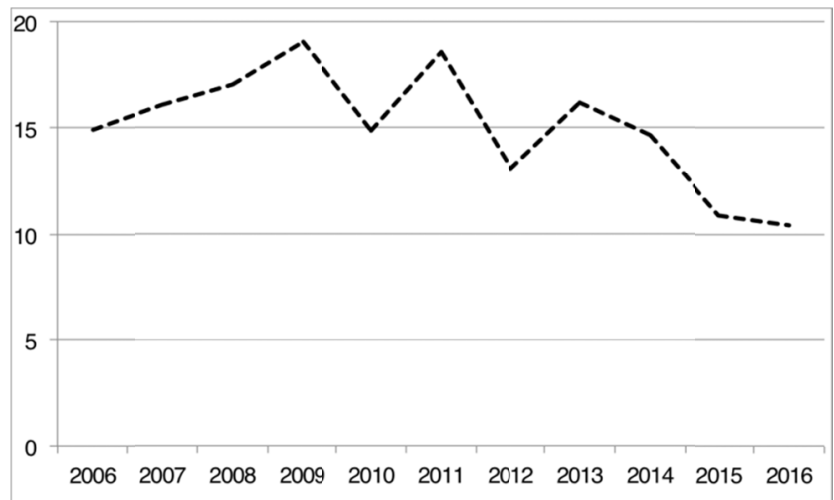

Figure 7. Average profit margin percentage of sales for gambling operators in Italian regulated sports betting market. Years 2006-2016

Source: our processing of data from Agency of Customs and Monopoly.

Naturally, the percentage decline in profit margins was more than offset, in absolute terms, by increasing the total amount wagered. The absolute profit margin of the sport betting industry, which in 2006 was equal to 386 million euro, reached 904 million euro in 2016, even if this turnover is divided between a much larger number of gambling operators compared to 2006.

\section{Conclusions}

The analysis carried out has allowed us to examine the main changes induced by e-commerce on the industrial structure and competition in the Italian regulated sports betting market. Looking at these changes as a whole, it is also possible to assess whether they lead to higher competitive pressure for gambling operators, in line with the popular view that the Internet increases industry competition (Porter, 2001), or if, on the contrary, they suggest the opposite hypothesis that favors the winner-take-all-structure of the Internet economy (Frank \& Cook, 1996), thus favoring a consolidation process with decreased industry competition.

To clarify this aspect, it is useful to carry out some summary considerations on the specific aims achieved.

The analysis showed, firstly, that since the full legalization of on-line betting carried out in 2006 under the new rules laid down by the Bersani Decree, there has been a significant increase in sales that has led the sector to exceed, in 2017, 12 billion euros of bets placed, compared to five times lower values that had been reached ten years earlier. The expansion of the market in terms of sales in Italy is influenced by an increase in on-line sales which, having reached a value of 6.5 billion euros in 2017, has for the first time exceeded the sales volume achieved by the land-based venues. The in-depth analysis carried out has made it possible to highlight, in this regard, that the success of Internet gambling seems to be the consequence of the numerous advantages perceived by Italian consumers - in terms of time, quality of consumer experience, range of consumer choice, level of available information and economic convenience - in the utilization, for access to on-line sports betting, of the electronic distribution channel, instead of the physical distribution channel. 
The analysis also revealed that the complete legalization of on-line betting has led to a lowering of barriers to enter into the Italian regulated market, facilitating the entry of numerous foreign gambling operators. These companies, leveraging the Internet sales channel, have been able to replicate the gambling services already provided in other countries, without having to sustain the huge investments necessary for the management of a widespread network of sales points, which were until then necessary to sell bets to a large number of consumers. In fact, the processing of market data has revealed that in recent years the foreign gambling operators, especially those specialized in the on-line distribution, have rapidly eroded the sales of Italian multichannel operators who for years have controlled almost exclusively the betting market - coming to control more than two thirds of the gambling volume in the sports betting industry in Italy.

The entry of new foreign gambling operators, connected to the development of on-line gambling, has affected the level of competition in the sector, as it emerges from the measurements of the data, for the period 2007-2017, of the industry concentration ratio. In fact, data processing showed a significant reduction, particularly in recent years, in the concentration of sales of the sports betting market in Italy. There has therefore been a shift in the strong oligopolistic structure that for decades has characterized the Italian betting industry. This change that, in terms of trends, will be further supported by an ever-increasing international openness of the Italian on-line betting market.

The transformations described also suggest an increase in the sector's competition, from the point of view of price. The impact of e-commerce on price levels of sports betting in Italy was therefore analyzed to also verify if, in line with theoretical hypothesis, the introduction of on-line betting had lead to a reduction in average prices charged from gambling operators. The analysis showed that the annual take-out rate for sports betting - an indicator of the price of sports bets - decreased from about 26 percent in 2006, to just over 13 percent in 2017, describing an average percentage decrease in prices of almost 50 percent. This decrease is linked to an average percentage price of on-line sports bets that has remained consistently lower by about 40 percentage points in relative terms, compared with the average price of sports bets sold through physical betting shops.

Finally, the increase of pricing competition also impacted on profit margins of companies operating in the sector. The data processed allowed us to show, in this regard, that the average profit margin for every euro bet decreased in a decade by about a third, from 15 percent in 2006, to 10 percent in 2016.

In conclusion, this research work as a whole has made it possible to highlight that the development of Internet technologies and of e-commerce has on the one hand had a positive influence on the growth of market sales; on the other hand, it has impacted on a series of structural factors in the sector - entry barriers, number of competitors, the geographical opening of the market, level of pricing, average profit margins - in such a way as to determine an increase in industry competition. In particular, the use by foreign companies of the electronic distribution channel as a 'mode of entry' into different geographical markets is causing the development of competition that goes beyond national borders. The data in terms of trends leads to the hypothesis that in the next few years, in the sports betting industry, more and more leadership positions will taken on by large Internet pure players, which will act transversally in different territorial contexts.

\section{References}

Agency of Customs and Monopoly. (2017a). Il gioco legale in Italia. Serie storica nazionale per canale distributivo 2013-2016. Documents, Monopoli Area, Retrieved from https://www.adm.gov.it/portale/documents/20182/1098450/Serie+storica+nazionale+per+canale+distributiv o+2013-2016.pdf/

Agency of Customs and Monopoly. (2017b). Il gioco legale in Italia. Serie storica nazionale 2006-2016. Documents, Monopoli Area, Retrieved from https:/www.adm.gov.it/portale/documents/20182/1098450/Serie+storica+nazionale+2006-2016.pdf/

Alba, J., Lynch, J., Weitz, B., Janiszewski, C., Lutz, R., Sawyer, A., \& Wood, S. (1997). Interactive home shopping: consumer, retailer, and manufacturer incentives to participate in electronic marketplaces. Journal of Marketing, 61(3), 38-53. http://www.jstor.org/stable/1251788 .

Ancarani, F., \& Shankar, V. (2004). Price levels and price dispersion within and across multiple retailer types: further evidence and extension. Journal of the Academy of Marketing Science. 32(2), 176-187. https://doi.org/10.1177/0092070303

Ansalone, V., \& Cestari, M. (2013). I principi comunitari ed i rapporti con l'Unione Europea. In G. Fidone, \& A. Linguiti (Eds.), La disciplina dei giochi in Italia tra monopolio pubblico e mercato (pp. 1-49). Napoli, Italia: Giuffrè Editore. 
Bailey, J. P. (1998). Electronic commerce: prices and consumer issues for three products: books, compact discs, and software. Working paper $O C D E / G D, 4(98)$. Organization for Economic Co-Operation and Development. Retrieved from http://www.oecd.org/dsti/sti/it/ec/prod/ie98-4.pdf.

Bakos, J. Y. (1997). Reducing buyer search costs: implications for electronic marketplaces. Management Science, 43(12), 1676-1692. https://doi.org/10.1287/mnsc.43.12.1676

Bakos, Y., Lucas, H., Oh, W, Simon, G., Viswanathan S., \& Weber, B. (2005). The impact of e-commerce on competition in the retail brokerage industry. Information Systems Research, 16(4), 352-371. https://doi.org/10.1287/isre.1050.0064

Bonanni, S. (2008). Lotta ai siti illegali: 1500 vengono oscurati, Agicos-La Repubblica, Sezione Giochi e scommesse, 27 novembre.

Brindley, C. (1999). The Marketing of Gambling on the Internet. Internet Research, 9(4), 281-286. http://doi.org/10.1108/10662249910286798

Brown, J. R., \& Goolsbee, A. (2002). Does the Internet make markets more competitive? Evidence from the life insurance industry. Journal of Political Economy, 110(3), 481-507. https://doi.org/10.1086/339714

Brynjolfsson, E., \& Smith, M. D. (2000). Frictionless commerce? A comparison of internet and conventional retailers. Management Science, 46(4), 563-585. https://doi.org/10.1287/mnsc.46.4.563.12061

Calvosa, P. (2016). Loyalty Typologies and Consumer Choice Factors in the Online Sports-Betting Industry: An Explorative Study into the Italian Regulated Market. International Journal of Marketing Studies, 8(5), 1-14. https://doi.org/10.5539/ijms.v8n5p1

Cestari, M. (2013). Le scommesse a quota fissa. In G. Fidone, \& A. Linguiti (Eds.), La disciplina dei giochi in Italia tra monopolio pubblico e mercato (pp. 141-146). Napoli, Italia: Giuffrè Editore.

Chóliz, M. (2016). The challenge of online gambling: The effect of legalization on the increase in online gambling addiction. Journal of Gambling Studies, 32, 749-756. http://dx.doi.org/10.1007/s10899-015-9558-6

Clay, K., Krishnan, R., Wolff, E., \& Fernandes, D. (2002). Retail Strategies on the Web: Price and Non-Price Competition in the Online Book Industry. The Journal of Industrial Economics, 50(3), 351-367. Retrieved from http://www.jstor.org/stable/3569810

Collesei U., Casarin F., \& Vescovi, T. (2001). Internet e i cambiamenti nei comportamenti di acquisto del consumatore. Micro \& Macro Marketing, 10(1), 33-50. https://doi.org/10.1431/2878

Coryn, T., Fijnaut, C., \& Littler, A. (2007). Economic Aspects of Gambling Regulation: EU and US Perspectives, Leiden, Boston: Martinus Nijhoff Publishers.

Eadington, W. R. (2004). The future of online gambling in the United States and elsewhere. Journal of Public Policy and Marketing, 23(2), 214-219. http://dx.doi.org/10.1509/jppm.23.2.214.51399

Fidone, G., \& Linguiti, A. (Eds.). (2013). La disciplina dei giochi in Italia tra monopolio pubblico e mercato. Napoli, Italia: Giuffrè Editore.

Frank, R. H., \& Cook, P. J. (1996). The Winner-Take-All Society. New York, NY: Martin Kessler Books.

Friberg, R., Ganslandt, M., \& Sandström, M. (2000). E-commerce and prices, Theory and Evidence, SSE/EFI Working Paper Series in Economics and Finance, N. 389, Stockholm School of Economics, 1-29. Retrieved from http:/hdl.handle.net/10419/56306

Gainsbury, S. (2012). Internet gambling: Current research findings and implications. New York: Springer.

Gainsbury, S. M., Russell, A., Hing, N., Wood, R, Lubman, D., \& Blaszczynski, A. (2015). How the Internet is Changing Gambling: Findings from an Australian Prevalence Survey. Journal of Gambling Studies, 31(1), 1-15. https://doi.org/10.1007/s10899-013-9404-7

Gainsbury, S., \& Wood, R. (2011). Internet gambling policy in critical comparative perspective: The effectiveness of existing regulatory frameworks. International Gambling Studies, 11(3), 309-323. http://dx.doi.org/10.1080/14459795.2011.619553

Gainsbury, S., Parke, J., \& Suhonen, N. (2013). Consumer attitudes towards Internet gambling: Perceptions of responsible gambling policies, consumer protection, and regulation of online gambling sites. Computers in Human Behavior, 29(1), 235-245. http://dx.doi.org/10.1016/j.chb.2012.08.010 
Gandolfo, A., \& De Bonis, V. (2011). Evoluzione e innovazione del gioco pubblico in Italia: analisi esplorativa di un mercato in rapido cambiamento. Finanza Marketing e Produzione, 3, 105-137.

Gandolfo, A., \& De Bonis, V. (2013). Il modello italiano di tassazione del gioco d'azzardo: linee guida di politica fiscale per lo 'sviluppo sostenibile' di un mercato importante e controverso. Discussion paper 137, Collana di E-papers del Dipartimento di Scienze Economiche, Università di Pisa. Retrieved from https://www.ec.unipi.it/documents/Ricerca/papers/2013-173.pdf

Goldmanis, M., Hortacsu, A., Syverson, C., \& Emre, O. (2010). E-Commerce and the Market Structure of Retail Industries. Economic Journal, 120, 651-682. https://doi.org/10.1111/j.1468-0297.2009.02310.x

Griffiths, M. (1999). Gambling technologies: Prospects for problem gambling. Journal of Gambling Studies, 15(3), 265-283. http://dx.doi.org/10.1023/A:1023053630588

Griffiths, M., \& Parke, J. (2002). The social impact of Internet gambling. Social Science Computer Review, 20(3), 312-320. http://dx.doi.org/10.1177/089443930202000308

Griffiths, M., Wood, R. T., \& Parke, J. (2009). Social responsibility tools in online gambling: A survey of attitudes and behavior among internet gamblers. Cyberpsychology \& Behavior, 12(4), 413-421. http://dx.doi.org/10.1089/cpb.2009.0062

Gropp, K., \& Kok, C. (2017). Competition and contestability in bank retail markets. In J. Bikker, \& L. Spierdijk (Eds.), Handbook of Competition in Banking and Finance (pp. 365-382). Northampton, Massachusetts, United States: Edward Elgar Publishing, Inc..

H2 Gambling Capital. (2013). There's nothing virtual about the opportunity in real-money gambling. Opportunities for Game Developers in Regulated Real-Money Online Gambling. Gibraltar: Odobo.

Jolley, B., Mizerski, R., \& Olaru, D. (2006). How Habit and Satisfaction Affects Player Retention for Online Gambling. Journal of Business Research, 59(6), 770-777. http://dx.doi.org/10.1016/j.jbusres.2006.01.017

Kairouz, I. F., Monson, E., \& Arsenault, N. (2018). Exploring the Effects of Introducing a State Monopoly Operator to an Unregulated Online Gambling Market. Journal of Gambling Issues Issue, 37, 137-148, http://dx.doi.org/10.4309/jgi.2018.37.6

Kauffman, R. J., \& Walden, E. A. (2001). Economics and Electronic Commerce: Survey and Directions for Research. International Journal of Electronic Commerce, 5(4), 5-116. https://doi.org/10.1080/10864415.2001.11044222

Lal, R., \& Sarvary, M. (1999). When and how is the Internet likely to decrease price competition? Marketing Science, 18(4), 485-503. Retrieved from https://pubsonline.informs.org/doi/abs/10.1287/mksc. 18.4 .485

Lee, Z., \& Gosain, S. (2002). A Longitudinal Price Comparison for Music CDs in Electronics and Brick-and-Mortar Markets: Pricing Strategies in Emergent Electronic Commerce. Journal of Business Strategies, 19(1), 55-71.

Li, B., Tang, F. F (2011). Online pricing dynamics in internet retailing: The case of the DVD market. Electronic Commerce Research and Applications, 10(2), 227-236. https://doi.org/10.1016/j.elerap.2010.06.004

Mataluni, F. (2013). La disciplina Italiana in materia di giochi e scommesse. In G., Fidone, \& A. Linguiti (Eds.), La disciplina dei giochi in Italia tra monopolio pubblico e mercato (pp. 61-140). Napoli, Italia: Giuffrè Editore.

Morton, F. S. F., Zettelmeyer, F., \& Silva-Risso, J. (2001). Internet car retailing. Journal of Industrial Economics, 49(4), 501-519. https://doi.org/10.1111/1467-6451.00160

Ozuem, W., \& Prasad, J. (2015). Online Social Gambling and Its Implications for the Study of Marketing Communications. International Journal of Applied Behavioral Economics, 4(3), 22-50. http://dx.doi.org/10.4018/IJABE.2015070102.

Pan, X., Ratchford, B. T., \& Shankar, V. (2004). Price dispersion on the Internet: a review and directions for future research. Journal of Interactive Marketing, 18(4), 116-135. https://doi.org/10.1002/dir.20019

Pandimiglio, A., \& Spallone, M. (2012). La valutazione economica delle innovazioni fiscali: metodologia e anticipazioni, CASMEF Working Paper Series, Luiss Guido Carli. Retrieved from http://static.luiss.it/RePEc/pdf/casmef/1108.pdf

Pilling, L., \& Bartlett, W. (2012). The Internet Gambling Industry. In R. J. Williams, R. T. Wood, \& J. Parke (Eds.), Routledge International Handbook of Internet Gambling (pp. 48-58). New York, NY: Routledge. 
Porter, M. E. (2001). Strategy and the Internet. Harvard Business Review. 79(3), 63-78. Retrieved from https://hbr.org/2001/03/strategy-and-the-internet

Rose, I. N. (2006). Gambling and the law: An introduction to the law of internet gambling. UNLV Gaming Research \& Review Journal, 10, 1-14. Retrieved from http://digitalscholarship.unlv.edu/grrj/vol10/iss1/1

Sabate, F., Cañabate, A., Cobo, E., \& García, D. (2009). Is the Internet making markets more efficient? The evidence according to price indicators in Spain, Intangible Capital, 5(2), 125-151. http://dx.doi.org/10.3926/ic.107

Sbordoni, S. (2010). Giochi concessi e gioco on line. Roma, Italia: Istituto Poligrafico dello Stato.

Simmonds, S. A., \& R. Sharp (1987). State lotteries' effects on thoroughbred horse racing. Journal of Policy Analysis and Management, 6(3), 446-448. Retrieved from https://www.jstor.org/stable/3324856

Sirianni, G. (2012). Il gioco pubblico dal monopolio fiscale alla regolamentazione, nella crisi dello Stato sociale. Diritto pubblico, 18(3), 801-836. http://dx.doi.org/10.1438/74204

Wang, F., \& Zhang, X. P. (2015). The role of the internet in changing industry competition. Information \& Management. 52(1), 71-81. https://doi.org/10.1016/j.im.2014.10.006

Wiebe, J. (2008), Internet gambling: Strategies to recruit and retain gamblers, Report Prepared for the Ontario Problem Gambling Research Centre, Guelph, ON. Retrieved from http://www.greo.ca/Modules/EvidenceCentre/files/Wiebe\%20\%282008\%29Internet_gambling_Strategies_t o_recruit_and_retain_gamblers.pdf

Williams, R., Wood, R., \& Parke, J. (2012). History, Current Worldwide Situation, and Concerns with Internet Gambling. In R. J. Williams, R. T. Wood, \& J. Parke (Eds.), Routledge International Handbook of Internet Gambling (pp. 3-25). New York, NY: Routledge.

Wood, R. T., \& Williams, R. J. (2007). Internet Gambling: Past, Present, and Future. In G. Smith. D. C. Hodgins, \& R. J. Williams (Eds.), Research and Measurement Issues in Gambling Studies (pp. 491-514). Boston: Elsevier.

Wood, R. T., Williams, R. J., \& Lawton, P. K. (2007). Why do Internet gamblers prefer online versus land-based venues? Some preliminary findings and implications. Journal of Gambling Issues, 20, 235-252. Retrieved from http://www.camh.net/egambling/issue20/pdfs/07wood.pdf

Woolley, R. (2003). Mapping Internet gambling: Emerging modes of online participation in wagering and sports betting. International Gambling Studies, 3(1), 3-21. http://dx.doi.org/10.1080/14459790304586

Yani-de-Soriano, M., Javed, U., \& Yousafzai, S. (2012). Can an industry be socially responsible if its products harm consumers? The case of online gambling. Journal of Business Ethics, 110(4), 481-497. http://dx.doi.org/10.1007/s10551-012-1495-z

Zettelmeijer, F., Morton S. J., \& Silva-Risso, J. (2006). How the Internet Lowers Prices: Evidence from Matched Survey and Automobile Transaction Data. Journal of Marketing, 43, 168-81. https://doi.org/10.1509/jmkr.43.2.168

\section{Notes}

Note 1. The total amount wagered is the sum of all individual bets in a period of time.

Note 2. It should be noted that in terms of Gross Gambling Revenue - based on the processing of data per individual operator provided by the Agency of Customs and Monopoly only from 2016 - the weight of Italian firms in 2017, while remaining below that of foreign companies, increased to around 43 percent. This is due to lower pay-outs on average paid by Italian companies compared to foreign ones.

Note 3. Only the Lottomatica/IGT group has adopted for past years a strategy of internationalization for some types of gambling.

Note 4. In particular, Lottomatica/IGT has the exclusive concession of Lotto and Lotteries, while Sisal has the exclusive concession of Superenalotto.

Note 5. It is right to point out that among Italian firms there are also a small number of small or medium-sized companies that operate exclusively on-line. For these companies, however, sales data is residual with respect to multi-channel companies. 
Note 6. In this regard, a decree law of 2012 ("Balduzzi decree") ordered that "the advertising of games involving cash prizes must report the percentage of winning odds that the subject has in the individual game", increasing the awareness of the players about the average prices of the different types of bets.

Note 7. This calculation does not include sales related to the Betting exchange as it is characterized by price dynamics different from other bets.

\section{Copyrights}

Copyright for this article is retained by the author(s), with first publication rights granted to the journal.

This is an open-access article distributed under the terms and conditions of the Creative Commons Attribution license (http://creativecommons.org/licenses/by/4.0/). 